\title{
Investigação defensiva: \\ a evolução do tema e os problemas de sua aplicabilidade
}

\author{
Defensive investigation: \\ dvelopment of subject and the problems of their applicability
}

\begin{abstract}
Marcelo Navarro Ribeiro Dantas
Universidade Nove de Julho (Uninove)

Doutor em Direito

Professor Associado do Curso de Direito da Universidade Federal do Rio Grande do Norte, ora em colaboração com a Faculdade de Direito da Universidade de Brasília. Professor Emérito da Universidade Nove de Julho.

Ministro do Superior Tribunal de Justiça Brasília/Distrito Federal/Brasil mnrdantas@uol.com.br

(iD João Carlos Faria da Costa

Universidade Nove de Julho (Uninove)

Mestrando em Direito Empresarial na Universidade Nove de Julho

Advogado

São Paulo/São Paulo/Brasil joao.costa@hslaw.com.br
\end{abstract}

Resumo: Pretende o presente trabalho analisar as atividades de investigação defensiva, abordando a partir dos precursores do tema até a materialidade de disposições normativas a respeito, trazendo seus contornos doutrinários e práticos. Além do mais, almeja o presente trabalho analisar e destacar a importância do assunto, principalmente seus aspectos contributivos para melhor instrução do processo acusatório, desde sua fase preliminar até sua aplicação na última fase da persecução penal. Inclusive, o resultado da pesquisa sobre a matéria objeto do presente trabalho científico revelará a importância da aplicação da investigação defensiva em prol de uma persecução penal que seja a mais justa possível.

Palavras-chave: investigação defensiva; contraditório; persecução penal; aplicabilidade; Provimento ${ }^{\circ}$ 188/2018 da OAB.

\begin{abstract}
The present work intends to analyze the activities of defensive investigation, approaching from the forerunners of the theme to the materiality of normative dispositions, in this respect, bringing its doctrinal and practical outlines. Furthermore, this work aims to analyze and highlight the importance of the matter, especially its contributing aspects for better instruction in the accusation process, from its preliminary phase to its application in the last phase of criminal prosecution. In fact, the result of the research on the subject matter of this scientific work will even reveal the importance of applying defensive investigation in favor of a criminal prosecution as fair as possible.
\end{abstract}

Keywords: defensive investigation; contradictory; criminal persecution; applicability; Provision $n^{\circ} 188 / 2018$ of the OAB. 


\section{Para citar este artigo}

ABNT NBR 6023:2018

DANTAS, Marcelo Navarro Ribeiro; COSTA, João Carlos Faria da. Investigação defensiva: a evolução do tema e os problemas de sua aplicabilidade. Prisma Jurídico, São Paulo, v. 20, n. 2, p. 351-374, jul./dez. 2021. http://doi.org/10.5585/prismaj.v20n2.21010.

\section{Introdução}

O tema da investigação defensiva vem gradativamente ganhando espaço no mundo jurídico, mesmo os resultados decorrentes de suas atividades terem ainda uma aceitação modesta no tocante a sua valoração pela autoridade a qual são apresentadas. Isso em razão de a investigação defensiva ainda encontrar resistência por parte de outras instituições, como o Ministério Público e a Polícia Judiciária. Mesmo diante desses desafios e resistências, as atividades de investigação defensiva são cada vez mais verificadas no campo probatório, especialmente em casos de alta complexidade, que por vezes demandam auxílio de detetives, peritos, contadores e outros profissionais habilitados na condução do caso. Por isso, o presente estudo busca analisar questões referentes à possibilidade de manejo da atividade investigativa também por parte daquele que é alvo de qualquer tipo de procedimento de investigação, diante da necessidade crescente do acompanhamento deste indivíduo, principalmente na fase que antecede a persecução penal propriamente dita.

A pesquisa inicia trazendo a atenção do tema por operadores do direito já há alguns anos e como o desenvolvimento da Ciência do Direito propiciou a evolução das atividades de investigação defensiva. Também analisará importante marco entre os estudos e disposições atualmente existentes no Brasil, a estatuição existente no Código de Processo Penal Italiano e a prática adotada pelos Estado Unidos da América. Da mesma forma, destacará a similitude entre as atividades de investigação defensiva, como previstas na doutrina, com a possibilidade de o investigado, por meio de seu defensor, promover entrevistas com pessoas a fim de colherlhes depoimentos para subsidiar a defesa de seus direitos.

Além disso, irá se ver, malgrado a doutrina ainda incipiente e a quase inexistente jurisprudência - que seria tão necessária para resolver o impasse acerca da constitucionalidade do instituto - a evolução de instrumentos normativos que materializaram a investigação defensiva, como o Provimento $n^{\circ}$ 188/2018, do Conselho Federal da Ordem dos Advogados do Brasil, e também avaliará propostas que, se aprovadas pelo Congresso Nacional, comporão o novo Código de Processo Penal. 
Portanto, por meio da revisão bibliográfica sobre o tema, o estudo verificará a possível viabilização da investigação defensiva, a fim de subsidiar posicionamentos e conclusões a respeito desse complexo de atividades utilizáveis para resguardar a paridade de armas em relação à investigação criminal, bem como garantir, de modo ainda mais efetivo, o contraditório. Com a presente pesquisa, espera-se facilitar a compreensão das atividades de investigação defensiva, que não é propriamente nova, mas certamente, em face de óbices que serão aqui discutidos, ainda pouco aplicada no exercício do direito de defesa.

\section{Conceituação de investigação defensiva}

De início, é importante apresentar o conceito de investigação defensiva para maior e melhor compreensão do presente trabalho.

Em razão disso, nada melhor que trazer a disposição contida no Provimento $\mathrm{n}^{\circ}$ 188/2018, do Conselho Federal da Ordem dos Advogados do Brasil, que tratou de normatizar o instituto:

Art. $1^{\circ}$ Compreende-se por investigação defensiva o complexo de atividades de natureza investigatória desenvolvido pelo advogado, com ou sem assistência de consultor técnico ou outros profissionais legalmente habilitados, em qualquer fase da persecução penal, procedimento ou grau de jurisdição, visando à obtenção de elementos de prova destinados à constituição de acervo probatório lícito, para a tutela de direitos de seu constituinte. (ORDEM DOS ADVOGADOS DO BRASIL, 2018).

Nesse mesmo sentido, não se pode falar de investigação defensiva sem citar Édson Luís Baldan, um dos precursores e defensor do tema. Para ele, investigação defensiva:

[...] é o complexo de atividades de natureza investigatória desenvolvido, em qualquer fase da persecução criminal, inclusive na antejudicial, pelo defensor, com ou sem assistência de consultor técnico, tendente à coleta de elementos objetivos, subjetivos e documentais de convicção, no escopo de construção de acervo probatório lícito que, no gozo da parcialidade constitucional deferida, empregará para pleno exercício da ampla defesa do imputado em contraponto à investigação ou acusação oficial. (BALDAN, 2007, p. 269)

Para Talon (2020, p. 68), a investigação defensiva se constitui numa prática desenvolvida pelo advogado, de forma isolada ou com a participação de terceiros, como detetives, peritos, contadores e outros, composta de várias atividades, de modo similar ao inquérito policial e à investigação direta realizada pelo Ministério Público.

Em idêntica trilha, Melo, Faria e Broeto (2020) lembram que, no Brasil, investigação defensiva é entendida como o complexo de atividades de natureza investigatória, desenvolvido pelo Advogado, com ou sem assistência de consultor técnico ou outros profissionais legalmente 
habilitados, em qualquer fase do processo penal, procedimento ou grau de jurisdição, visando à obtenção de elementos de prova destinados à constituição de acervo probatório lícito, para a tutela de direitos de seu constituinte.

Já o art. $2^{\circ}$ do referido Provimento nº 188/2018 estabelece que a investigação defensiva pode ser desenvolvida na etapa da investigação preliminar, ou seja, fase antejudicial; no decorrer da instrução processual em juízo; na fase recursal em qualquer grau, inclusive durante a execução penal; e, ainda, como medida preparatória para a propositura da revisão criminal ou em seu decorrer.

Por conseguinte, ao abordarem o artigo $3^{\circ}$ do Provimento, Valber Melo, Fernando Faria e Filipe Maia Broeto ressaltam:

\begin{abstract}
$\mathrm{O}$ art. $3^{\circ}$ do Provimento estabelece que a investigação defensiva, sem prejuízo de outras finalidades, orienta-se, especialmente, para a produção de elementos que venham a fundamentar pedidos de instauração ou até de trancamento de inquérito; rejeição ou recebimento de denúncia ou queixa; resposta à acusação; pedido de medidas cautelares; defesa em ações penais (pública ou privada); razões de recurso; revisão criminal; habeas corpus; acordo negocial (colaboração premiada, leniência e de não persecução penal), como outras medidas destinadas a assegurar os direitos individuais em procedimentos de natureza criminal. (MELO; FARIA; BROETO, 2020).
\end{abstract}

Por sua vez, o art. $4^{\circ}$ do Provimento no $188 / 2018$ estabelece ao advogado, na condução da investigação defensiva, a faculdade de promover diretamente todas as diligências investigatórias necessárias ao esclarecimento do fato apurado, especialmente por meio de colheita de depoimentos; pesquisa e obtenção de dados e informações disponíveis em órgãos públicos ou privados; determinar a elaboração de laudos e exames periciais; e realizar reconstituições, ressalvadas as hipóteses de reserva de jurisdição. É de salutar relevância destacar que o Provimento autoriza o advogado, durante as atividades da investigação defensiva, se valer de colaboradores, como detetives particulares, peritos, técnicos e auxiliares de trabalhos de campo.

Adiante, quanto ao art. $5^{\circ}$ do mencionado provimento, pontuam os mesmos autores que, em observância a preceitos constitucionais, como o art. $5^{\circ}, \mathrm{X}$, da Constituição da República, durante a realização da investigação, o advogado deve cercar-se de redobrados cuidados, a fim de resguardar o sigilo das informações apuradas, além de preservar a dignidade da pessoa humana, a privacidade, a intimidade e os demais direitos e garantia individuais.

Outro ponto que merece destaque no Provimento $n^{\circ} 188 / 2018$, que caminha ao encontro do princípio nemo tenetur se detegere (o direito de não produzir prova contra si mesmo), diz respeito ao seu art. $6^{\circ}$, uma vez que resguarda tanto o advogado como os outros profissionais 
que prestarem assistência na investigação defensiva, quanto à inexistência do dever de informar à autoridade competente os fatos descobertos na investigação; e que, eventual comunicação e publicidade do resultado da investigação precisam necessariamente de expressa autorização do constituinte.

Quanto a esse ponto, abrem-se parênteses à conceituação do tema para registrar que tais disposições foram alvos de objeção por Silva (2019), pois em sua visão, não seria razoável que a polícia judiciária e o Ministério Público realizem investigações e colham provas na busca pela verdade real, enquanto a Defesa, realizando a investigação particular, se depare com provas contrárias ao constituinte, e opte por sonegá-las.

Entretanto, no exercício da figura de acusação, o próprio Ministério Público seleciona as provas que almeja subsidiar sua versão quando do oferecimento da peça acusatória. Evidentemente, na posição de órgão acusador, utiliza-se das provas colhidas que apontam para eventual ilicitude praticada pelo acusado, não informando as provas que eventualmente apontem em sentido contrário à acusação. Tal temática tem sido alvo de debates jurídicos na Academia e no Parlamento, à luz do que já observado no Direito Comparado, notadamente o alemão, constando hoje de projeto de lei batizado de Anastasia-Streck e que já foi alvo da atenção de alguns de nossos maiores doutrinadores (PRADO, 2020).

Prado (2020) esclarece que a proposta — que impõe à acusação o dever de informar tudo o que desvendar, mesmo que seja informação ou prova em prol do investigado - , foi incorporada e convertida em projeto de lei pelo Senador Antonio Anastasia (PSD-MG), a partir de estudos de Lenio Streck, cujo objetivo é alterar o artigo 156 do Código de Processo Penal para o fim de "estabelecer o dever de o Ministério Público, ciente de elementos na investigação criminal que possam interessar à defesa do investigado, diligenciar no sentido do esclarecimento da verdade". Salienta ainda o Autor que o "dever de lealdade da acusação deixa de ser apenas um mandamento ético para transformar-se em 'dever jurídico."”

Se essa ideia de fato virar lei, a investigação defensiva vai se deparar com um novo questionamento, porque em princípio não parecerá razoável justificar que um lado tenha de desvelar tudo, e o outro, não. Ainda que se possa buscar justificar, talvez, tal privilégio, em nome da presunção de inocência... De todo modo, isso é assunto para outro artigo, escapando do escopo do presente.

Para enfeixar este ponto, e retomando a conceituação da investigação defensiva, o art. $7^{\circ}$ do Provimento $n^{\circ}$ 188/2018 estabelece que as atividades da investigação defensiva consignadas no referido ato normativo são privativas da advocacia, compreendendo-se como 
ato legítimo de exercício profissional, não podendo, dessarte, receber qualquer tipo de censura ou impedimento pelas autoridades.

Com efeito, constata-se que a investigação defensiva trata em verdade de um conjunto de atividades a serem realizadas pelo defensor, por si mesmo ou com o auxílio de profissionais ligados à matéria objeto da investigação estatal, independentemente de esta ter se iniciado ou findado. Assim sendo, a investigação defensiva compõe a reunião de um conjunto de elementos probatórios, lícitos, capaz de subsidiar a defesa dos direitos do investigado.

\section{A evolução do tema investigação defensiva}

Para compreender a evolução do tema investigação defensiva, o estudo pautou-se em verificar a motivação propulsora dessa questão, identificando a causa raiz de sua problematização.

Há tempos se discute o papel da defesa na primeira fase da persecução criminal, ou seja, na fase preliminar de investigação, ou ainda, antes da fase judicial da imputação criminal do agente. Principalmente no inquérito policial ou em procedimento instaurado pelo próprio Ministério Público, normalmente nomeado como Procedimento Investigatório Criminal (PIC), em geral não se verifica a presença ativa do investigado na tramitação do feito investigatório.

Conforme registra Baldan, diante da escassez de regulamentação a fim de assegurar maior participação da defesa na fase preliminar, diversos agentes e órgãos do Estado exercem a investigação criminal, sem, contudo, a presença, aqui entendida como proximidade e possibilidade de atuação da defesa, nas atividades executadas pela investigação, sendo, especialmente três situações, como cita o autor:

(i) interceptação telefônica inicial, por prazo indefinido, objetivando a coleta de
indícios que motivarão (ii) o decreto de uma prisão cautelar que (iii) a sua vez, será
empregada como instrumento de coação sobre o imputado, instado sem recatos pelos
investigantes e acusadores a confessar e delatar, tendo a própria liberdade como objeto
de vergonhosa e desigual barganha. (BALDAN, 2007, p. 257).

Todavia, essas condições não parecem traduzir o espírito constitucional de paridade de armas entre acusação e defesa, sobressaindo tal discrepância principalmente na fase de investigação preliminar. E é nesse viés que a investigação defensiva galga, ainda a passos curtos, é verdade, em busca de uma participação mais efetiva do Defensor na fase de antejudicial. 
Lembra Zanardi (2016, p. 193) que a prova produzida na investigação prévia não está excluída da necessidade de observância ao contraditório, nitidamente contemplado na fase judicial.

Nesse sentido Baldan (2007, p. 249) registra que "não só o acusado (na fase judicial) mas também o imputado (na fase preliminar de investigação ou, mesmo, aquém desta) deve gozar, na plenitude da garantia individual do devido processo legal.”

Tanto assim é que, num passado não muito distante, o próprio franqueamento dos autos de procedimento investigatório passou a ser tema sumulado pelo Egrégio Supremo Tribunal Federal, que, por meio da Súmula Vinculante n. 14, assim dispôs:

É direito do defensor, no interesse do representado, ter acesso amplo aos elementos de prova que, já documentados em procedimento investigatório realizado por órgão com competência de polícia judiciária, digam respeito ao exercício do direito de defesa. Publicada em 09.02.2009. (BRASIL. Supremo Tribunal Federal, 2009).

Apurou-se, pela pesquisa, que o posicionamento adotado pelo Egrégio Supremo Tribunal Federal caminha em consonância com os direitos do advogado previstos nos incisos do art. $7^{\circ}$ da Lei $n^{\circ} 8.906$, de 4 de julho de 1994 - Estatuto da Advocacia e a Ordem dos Advogados do Brasil (OAB) —, notadamente a possibilidade de exercer com liberdade a profissão; de comunicar-se com seus clientes, pessoal e reservadamente, mesmo sem procuração, quando estes se acharem presos, detidos ou recolhidos em estabelecimentos civis ou militares, ainda que considerados incomunicáveis; ingressar livremente em cartórios, ofícios de justiça, delegacias, entre outros; reclamar perante qualquer juízo, tribunal ou autoridade, contra a inobservância de preceito de lei, regulamento ou regimento; examinar, em qualquer órgão do Poder Público, autos de processos findos ou em andamento, mesmo sem procuração, quando não estiverem sujeitos a sigilo ou segredo de justiça, assegurada a obtenção de cópias, com possibilidade de tomar apontamentos; examinar, em qualquer instituição responsável por conduzir investigação, mesmo sem procuração, autos de flagrante e de investigação de qualquer natureza, findos ou em andamento, ainda que conclusos à autoridade, podendo copiar peças e tomar apontamentos, em meio físico ou digital; e ter vista dos processos judiciais ou administrativos de qualquer natureza, em cartório ou na repartição competente, ou retirá-los pelos prazos legais.

Conforme bem ponderou Machado (2009, p. 77-79) ao mencionar o princípio do contraditório, antes de se tratar de uma garantia processual, constitui ele, na verdade, elemento essencial da definição de processo, servindo como fator que legitima a decisão proferida. 
Assim, verificou-se que a preocupação com a observância do contraditório, notadamente na fase preliminar da investigação, passou a ter destaque no campo científico, na tentativa de maximizar a penetração da efetiva participação do defensor nesse momento tão relevante da persecução penal: a investigação.

Nesse sentido, ainda no ano de 2007, Baldan (2007, p. 269) já expressava publicamente a preocupação com a necessidade da participação da defesa na fase preliminar da investigação, pois os vícios do inquérito policial podem contaminar de forma irremediável a ação penal.

Explica Baldan que o direito de defesa do investigado na fase preliminar da persecução penal representa uma garantia com duas faces: uma, formal, consistente no direito de produzir provas; outra, material, referente ao direito à preservação da liberdade, da moral, do patrimônio. Nessa esteira, comenta a Lei $n^{\circ} 397$, de 7 de dezembro de 2000, que alterou os arts. 327 e 391 do Código de Processo Penal da Itália, trazendo novas possibilidades para o advogado exercer o múnus da defesa do investigado, que são:
a) entrevistar pessoal e informalmente potenciais testemunhas;
b) colher declaração escrita de pessoas, com a cominação de crime de falso testemunho;
c) requerer laudos periciais ou, então, produzi-los através de assistentes técnicos;
d) efetuar vistoria em coisas ou inspecionar lugares públicos ou privados;
e) solicitar documentos em poder da Administração Pública, deles extraindo cópias;
f) formar o instrumento para documentação dessas atividades. (BALDAN, 2007, p. 271).

Outrossim, os Estados Unidos da América são exemplos na adoção e difusão da investigação defensiva. Naquela nação, conforme pontua Machado (2009, p. 99), a investigação é realizada comumente pelos órgãos de polícia. Entretanto, tal atividade não é exclusividade da polícia judiciária, tendo nos últimos anos algumas investigações sido realizadas por promotores (ou Procuradores da República).

Nessa mesma perspectiva, a figura da investigação defensiva ocupa papel de grande destaque, principalmente na fase anterior à judicial. Isso porque, conforme esclarece Machado (2009, p. 100), citando João Gualberto Garcez, a Justiça criminal dos Estados Unidos da América é extremamente onerosa e, por conta disso, as provas são produzidas fora dos autos e depois anexadas a eles. Comenta ainda que é comum que tanto as promotorias, como os grandes escritórios de advocacia, contem com notários para auxiliar na produção de depoimentos préprocessuais, tendo inclusive a possibilidade de os depoimentos serem acompanhados pela parte contrária. 
Com isso, o Autor conclui que a investigação defensiva nos Estados Unidos da América é plenamente admissível, decorrente até mesmo de seu regime jurídico, o qual atribui às partes a iniciativa investigatória e probatória (MACHADO, 2009, p. 101).

Foi diante desse processo evolutivo e de maturação do tema que, no ano de 2018, as atividades de investigação defensiva foram expressamente reconhecidas por meio do Provimento no 188/2018 do Conselho Federal da Ordem dos Advogados do Brasil.

É importante destacar que, além da conceituação das atividades investigatórias desenvolvidas pelo advogado, bem como a possibilidade ou não de os trabalhos serem desenvolvidos com assistência de outros profissionais legalmente habilitados, consignou-se também que as atividades investigativas poderão se dar em qualquer fase da persecução penal, sejam quais forem os procedimentos ou graus de jurisdição, conforme se depreende do art. $1^{\circ}$ do referido provimento. Nesse mesmo sentido são as diretrizes do seu art. $2^{\circ}$, tendo consignado que a "investigação defensiva pode ser desenvolvida na etapa da investigação preliminar, no decorrer da instrução processual em juízo, na fase recursal em qualquer grau, durante a execução penal e, ainda, como medida preparatória para a propositura da revisão criminal ou em seu decorrer."

Outro aspecto importante trazido pelo Provimento $n^{\circ} 188 / 2018$, é a faculdade de o advogado realizar diretamente todas as diligências investigatórias necessárias ao esclarecimento dos fatos, especialmente a colheita de depoimentos, pesquisa e obtenção de dados e informações em órgãos públicos ou privados, determinar a elaboração de laudos e exames periciais, e realizar reconstituições, excetuadas as hipóteses de reserva de jurisdição, valendo-se inclusive de detetives particulares, peritos, técnicos e auxiliares de trabalhos de campo.

Como bem pontuaram Augusto Eduardo de Souza Rossini e Spencer Toth Sydow:

Tal provimento vai de encontro à ${ }^{1}$ prática da advocacia em países como os Estados Unidos da América do Norte que, ao delegar ao advogado a composição da prova, reforça a necessidade de que todas as partes do processo penal devem envidar esforços para atingir a verdade dos fatos. (ROSSINI; SYDOW, 2020).

Dessa forma, verificou-se significativo avanço quanto ao tema da investigação defensiva, inclusive deixando o campo da tese para se materializar, normativamente e com contornos definidos, em decorrência do Provimento ${ }^{\circ}$ 188/2018, do Conselho Federal da Ordem dos Advogado do Brasil.

\footnotetext{
${ }^{1}$ Sic, mas deveria ser vai ao encontro da.
} 


\section{A investigação defensiva e o contraditório na fase preliminar da persecução}

Diante do caráter investigativo do inquérito policial ou do procedimento investigatório criminal promovido pelo Ministério Público, trata de ponto sensível o assunto a respeito da admissão das atividades de investigação defensiva na fase preliminar da persecução penal.

A pesquisa constatou posicionamentos completamente divergentes sobre observância do contraditório em sede antejudicial.

Assinalou Machado (2009, p. 84) que, a discussão sobre a incidência do contraditório e do direito de defesa no inquérito policial existe desde antes da Constituição de 1988. Nesse sentido, cita posição de José Frederico Marques, que defendia a impossibilidade de se tolerar o contraditório em inquérito, sob pena de fracassarem as investigações policiais. Em sentido contrário, o Autor lembra o posicionamento de Joaquim Canuto Mendes de Almeida, defensor da defesa na fase investigatória, na medida em que o inquérito policial se destina a servir de base à denúncia ou queixa, e, portanto, obstaculizar a defesa seria absolutamente contrária a qualquer senso de Justiça. Entretanto, o posicionamento vem com a ressalva de que esse direito de defesa não implicaria contraditório, uma vez que não caberia intervenção ampla das partes nessa fase preliminar.

Após o advento da Constituição Federal de 1988, Machado (2009, p. 85) discorre sobre o aumento da discussão sobre a incidência do contraditório e da ampla defesa na fase investigatória, em decorrência da redação trazida pelo art. $5^{\circ}, \mathrm{LV}$, da Constituição Federal. Isso porque existe o entendimento de que os termos "processo administrativo" e "acusados em geral” do inciso LV, se aplicariam à fase investigatória, na medida em que o inquérito policial corporifica procedimento administrativo pré-processual, não podendo a norma garantista da Constituição Federal ser vista de forma restritiva, como defende Lopes Júnior (2005, p. 309311).

Além do mais, o mesmo doutrinador comenta o reforço a essa corrente feito por Rogério Lauria Tucci, por entender que a persecução penal toda deve ser formada por um contraditório efetivo e real, o que inclui, por certo, a fase preliminar. (MACHADO, 2009, p. 85).

Na visão de Pedrosa (2019, p. 47-72), a ampla defesa é "elementar típica" do contraditório. Em razão disso, autoriza que o cidadão busque todo e qualquer elemento probatório a subsidiar sua alegação, desde que respeitados os limites legais.

Para Milanezi (2020), a lei não pode ser analisada com frieza, e se esquecer que pessoas são afetadas pelo resultado da persecução criminal. Registra ainda que, somente com a 
observância do contraditório, da ampla defesa e da paridade de armas, se pode chegar a um "resultado minimamente justo".

Em continuidade, Milanezi (2020) entende que o inquérito policial é a base do processo criminal, sendo ele, portanto, construído a partir da investigação. Em razão disso, consigna que negar a atuação da advocacia defensiva viola a prerrogativa do advogado, prevista no art. $7^{\circ}, \mathrm{I}$, XXI, e outros dispositivos, do Estatuto da OAB. Nessa linha, lembra que constitui direito da sociedade a realização de atos não contrários à lei, os quais refogem ao que se denomina princípio da taxatividade, ao contrário do agente público, que só pode fazer o que a lei autoriza.

A propósito, registra então a autora: "Não bastasse o exposto, os princípios da igualdade, devido processo legal, contraditório e ampla defesa são fundantes do sistema normativo pátrio. Os princípios vinculam a aplicação e interpretação da norma e servem de suporte à viabilidade da investigação criminal defensiva.” (MILANEZI, 2020).

Todavia, segundo Machado (2009, p. 86), os doutrinadores contrários à possibilidade de contraditório na fase pré-processual defendem que o preceito constitucional não autorizaria a extensão do contraditório ao inquérito policial, até porque, o texto constitucional apresenta “processo judicial ou administrativo", não sendo o que constitui um inquérito policial. Ademais, também não poderia ser possível o contraditório nessa fase preliminar, uma vez que não há acusado em tal procedimento, não havendo, portanto, conflito de interesses entres partes.

A par de ser extremamente complexo pretender importar do processo civil para o penal a problemática da lide, o autor em tela esclarece que essa corrente não significa a impossibilidade de intervenção do imputado em tal estágio, até porque se pode requerer diligências à autoridade policial, assim como acompanhar a tramitação do inquérito, a fim de evitar infundadas medidas cautelares eventualmente requeridas e até mesmo acusações equivocadas. Contudo, essa intervenção limitada do imputado não equivaleria ao contraditório. Além disso, salienta que, em determinados momentos do procedimento investigatório, como, por exemplo, a produção antecipada de provas, deve ser observado o contraditório.

Arrematando, André Augusto Mendes Machado chega à seguinte conclusão:

De fato, não se vislumbra contraditório no inquérito policial, por ser próprio de uma relação jurídico-processual, com a dialética que lhe é característica. Em contrapartida, é inegável que deve ser reservado ao imputado, em grau adequado, o direito de se defender da imputação que lhe foi feita nesta fase, para evitar a aplicação de medidas cautelares descabidas ou o advento de ação penal infundada. (MACHADO, 2009, p. 88).

Desse modo, verifica-se que ainda não existe consenso sobre a observância do contraditório na fase preliminar da persecução penal. Entretanto, é inconteste o direito de o 
imputado acompanhar e efetivamente participar da tramitação do procedimento investigativo, inclusive requerendo diligências e apresentando esclarecimentos, a fim de evitar conclusões equivocadas no curso das investigações que podem causar danos imensuráveis como medidas cautelares e até acusações infundadas. Essas razões evidenciam a relevância da investigação defensiva como meio para subsidiar as alegações do imputado nessa fase da persecução penal, contribuindo para a busca da verdade.

\section{A discussão sobre a suposta inconstitucionalidade da investigação defensiva}

Neste passo, a pesquisa encontrou dois pontos de vista distintos sobre a mesma questão, mas que convergem no final para o entendimento de ser inconstitucional a investigação defensiva. São eles: i) o ponto de vista da acusação; e ii) o da polícia judiciária.

\subsection{Ponto de vista da acusação}

Sob a ótica da acusação, Silva (2019), que é Promotor de Justiça, inicia o tema consignando que o Provimento $n^{\circ} 188 / 2018$, editado pelo Conselho Federal da Ordem dos Advogado do Brasil, seria flagrantemente inconstitucional, tanto no seu aspecto formal quanto material, uma vez que estaria criando normas processuais que contrariam as já existentes no Código de Processo Penal, por estabelecer uma investigação paralela à oficial.

Salienta ainda que não cabe à Ordem dos Advogados do Brasil criar norma jurídica com força vinculante para a autoridade pública, não sendo fonte material de Direito por não deter autorização da Constituição da República para criar regras legais processuais, nos termos do que dispõe o art. 22, I, da Carta Política. Ou, se se entender tratar-se de norma não processual, também não haveria guarida, em decorrência do que dispõe o art. 24, XI, ainda da Constituição. (SILVA, 2019).

Explica que, na investigação criminal realizada pela polícia judiciária ou pelo Ministério Público, não existe direito ao contraditório e à ampla defesa, por se tratarem de meros procedimentos investigativos a fim de averiguar a ocorrência de infração penal e sua autoria, podendo, após, ser proposta ação penal ou a promoção de seu arquivamento.

Esclarece também que, diferentemente do Provimento editado pela Ordem dos Advogado do Brasil, que atribuiu funções investigativas ao advogado, a resolução editada pelo Conselho Nacional do Ministério Público — notadamente se referindo à Resolução 181/2017, que dispõe sobre instauração e tramitação do procedimento investigatório criminal a cargo do 
Ministério Público - , esta última apenas regulamenta a investigação criminal pelo Parquet, fundada em decisão do Supremo Tribunal Federal ${ }^{2}$, o que não se verifica quando aos membros da OAB.

Concluindo, encerra César Dário Mariano da Silva com a seguinte crítica:

[...] por todos os ângulos que se examine, o provimento é inconstitucional, materialmente inexistente, não merecendo sequer ser observado pela autoridade pública, uma vez que oriundo de órgão que não possui ascendência sobre qualquer dos Poderes, mas apenas à classe dos advogados. (SILVA, 2019).

\subsection{Ponto de vista da polícia judiciária}

Neste viés, o Delegado de Polícia Civil Henrique Hoffmann e o Delegado de Polícia Federal Eduardo Fontes consignam que, nos termos previstos na Constituição Federal, a competência exclusiva para apuração de infrações penais comuns é da polícia judiciária, não podendo ser usurpada por órgãos públicos e privados (HOFFMANN; FONTES, 2019). Para esses autores, nos termos do art. $144, \S \S 1^{\circ}$ e $4^{\circ}$ da Constituição da República, a Polícia Federal e a Polícia Civil são os órgãos vocacionados para realizar a investigação criminal. E acrescentam que a Lei $n^{\circ} 12.830 / 13$, que dispõe sobre a investigação criminal conduzida pelo delegado de polícia, “deixa claro que a tarefa é, além de jurídica, essencial e exclusiva de Estado, devendo ser conduzida por delegado de polícia.”

Consignam ainda que a separação das funções (investigação, acusação e defesa) dentro da persecução penal é natural, na medida em que a evolução do processo penal buscou mais isenção na busca pela verdade.

Nessa perspectiva, posicionam-se contrariamente ao que denominam de apropriação da tarefa de investigação, seja a investigação realizada pelo Ministério Público, seja a investigação feita pela defesa. Destacam que, não importa se vítima, suspeito, detetive profissional ou mesmo advogado, ninguém pode realizar investigação defensiva, devendo, caso se deparem com fontes de prova, informar diretamente à polícia judiciária. E, quanto à investigação pelo Ministério Público, em que pese a decisão proferida pelo Supremo Tribunal Federal (RE

\footnotetext{
${ }^{2}$ Refere-se ao julgamento de Recurso Extraordinário com repercussão geral que decidiu: “O Ministério Público dispõe de competência para promover, por autoridade própria, e por prazo razoável, investigações de natureza penal, desde que respeitados os direitos e garantias que assistem a qualquer indiciado ou a qualquer pessoa sob investigação do Estado, observadas, sempre, por seus agentes, as hipóteses de reserva constitucional de jurisdição e, também, as prerrogativas profissionais de que se acham investidos, em nosso País, os Advogados (Lei 8.906/94, artigo $7^{\circ}$, notadamente os incisos I, II, III, XI, XIII, XIV e XIX), sem prejuízo da possibilidade sempre presente no Estado democrático de Direito - do permanente controle jurisdicional dos atos, necessariamente documentados (Súmula Vinculante 14), praticados pelos membros dessa instituição". (RE 593727/MG - Rel. Min. Cezar Peluso - Tribunal Pleno - j. em 14/05/2015).
} 
593727/MG), entendem que o PIC (Procedimento Investigatório Criminal) não possui previsão legal, uma vez que a Resolução 181/2017 é mero ato infralegal. Aliás, ressaltam que a chancela concedida ao Ministério Público "criou uma disparidade injustificável entre acusação e defesa." (HOFFMANN; FONTES, 2019).

No tocante à investigação defensiva sustentada por parte da doutrina com supedâneo nas garantias constitucionais da ampla defesa e do devido processo legal, além de tratados internacionais de que o Brasil é signatário, entendem os referidos delegados que tais princípios não possuem o condão de "criar novos órgãos de investigação criminal sem amparo expresso no ordenamento constitucional e legal". Até porque, concluem que o argumento de alguns doutrinadores de que a investigação defensiva estaria abarcada pela Convenção Americana de Direitos Humanos, em razão de seu artigo $8^{\circ}$, não se sustentaria, na medida em que tal disposição se referia a "garantias judiciais".

E, incisivamente, afirmam:

Como se nota, atos normativos infraconstitucionais têm se multiplicado e, ao inovarem no mundo do Direito, não resolvem os problemas que se propõem a curar e ainda incentivam um estado de coisas inconstitucional na segurança pública. Como se o desempenho de importantes funções que relativizam direitos fundamentais dos cidadãos fosse questão de menor importância, a dispensar deliberação do legislador constituinte e merecer simples deliberação interna corporis da acusação ou defesa.

Posto isso, verifica-se que a investigação defensiva continua encontrando grande resistência das outras figuras da persecução penal, polícia judiciária e acusação, cada qual com seu posicionamento específico e até mesmo um contra o outro. A verdade é que o tema continua em franca expansão e o diálogo na comunidade acadêmica e científica é de suma importância para pacificar a questão e uniformizar o entendimento quanto ao reconhecimento, aceitação e aplicabilidade da investigação defensiva, faltando, infelizmente, um posicionamento específico dos tribunais superiores.

\section{A (escassez de) jurisprudência}

Ademais da doutrina ainda incipiente — basta ver as referências desta pesquisa, quase todas de meros artigos, e a maioria publicados apenas em meio eletrônico - a investigação defensiva carece de jurisprudência, em especial das cortes maiores, capaz de suprir as dúvidas e até impasses aqui expostos. 
No Superior Tribunal de Justiça ela aparece em algumas decisões monocráticas, destacando-se a do Ministro Sérgio Kukina no MS 2.6627-DF (2020/0177090-7, DJ

01/09/2020) em que o impetrante invocou a técnica, merecendo a seguinte apreciação:

(...) a Defesa do IMPETRANTE, no exercício do legítimo interesse de conduzir Investigação Defensiva, objetivando a constituição de acervo probatório lícito, cujo direito lhe é assegurado em qualquer procedimento ou fase da persecução penal, nos termos do Provimento n. ${ }^{\circ}$ 188/2018 do Conselho Federal da OAB, realizou diligência administrativa aos 16.03 .2020 perante o DRCI, visando obter informações.

(...)

(...) No mérito, diante das informações públicas indicadas, (...) que seja concedida a segurança, a fim de que se franqueie acesso à cópia integral de todos os eventuais registros relativos ao intercâmbio de informações, contatos, encontros, provas, procedimentos e investigações entre as autoridades locais e norte-americanas (...), nos termos da Investigação Defensiva comunicada na origem (...), ou, então, para que referido órgão esclareça e certifique que não participou dessa cooperação internacional (...)

(...)

Como refere o impetrante, legítimo se revela o seu interesse em instruir, com tais informações (positivas ou negativas que sejam), noticiada Investigação Defensiva por ele deflagrada, em providência respaldada pelo Provimento 188/2018 do Conselho Federal da OAB. O periculum, nesse contexto, ressai da factível circunstância de que algumas das ações penais a que responde já se achariam em estágio avançado, urgindo, por isso, o acesso às informações buscadas nesta lide mandamental.

A orientação aqui adotada está a tomar como parâmetros não só as cláusulas constitucionais asseguradoras do direito à informação e da ampla defesa (art. $5^{\circ}$, incisos XXXIII e LV, respectivamente), como também importante diretriz posta na Lei de Acesso à Informação, que sinaliza no sentido da observância da publicidade como preceito geral e do sigilo como exceção (art. $3^{\circ}$, I, da Lei 12.527/11).

ANTE O EXPOSTO:

I - defiro, apenas em parte, o pedido de medida liminar, determinando à autoridade coatora (...) que informe ao impetrante, única e tão somente, sobre a existência, ou não, de pedidos de cooperação internacional formulados por autoridades Judiciárias brasileiras ou americanas (EUA), com base no acordo referido no Decreto 3.810/01, que tenham tramitado ou ainda tramitem perante a Autoridade Central brasileira (DRCI), tendo por foco as específicas 6 (seis) ações penais a que responde o impetrante (...); em caso de inexistirem pedidos de cooperação internacional relacionados aos mencionados processos penais, deverá a autoridade impetrada, do mesmo modo, informar acerca dessa inexistência; fixo, outrossim, o prazo de 5 (cinco) dias úteis , a contar da publicação desta decisão, para o atendimento da presente medida, comunicando-se a este relator sobre o seu cumprimento;

II - admito o ingresso da União, como requerido à fl. 958, ao tempo em que também defiro a juntada de documentos por ela solicitada às fls. 1.137/1.352;

III - proceda-se, outrossim, ao desentranhamento das informações prestadas pela autoridade impetrada (fls. 965/975), bem como dos documentos que as acompanham (fls. 976/1.130), tendo em vista que não dizem respeito ao presente writ, mas sim ao MS 26.625/DF, também de minha relatoria, ao qual devem ser prontamente direcionados e juntados;

IV - dê-se vista ao Ministério Público Federal (art. 12 da Lei n. 12.016/09);

$\mathrm{V}$ - oportunamente, voltem conclusos.

Cientifiquem-se a autoridade coatora e a parte impetrante, com urgência.

Publique-se. Cumpra-se.

(Grifou-se).

O decisum monocrático acima, como se viu, considerou legítima a investigação defensiva, ainda que sem ingressar em maiores considerações. 
Há ainda um acórdão - por sinal, da Corte Especial do Tribunal da Cidadania, reafirmando conclusão de sua $5^{\mathrm{a}}$ Turma - , ligado à mesma operação que deu azo à decisão anterior, que menciona o instituto e não o questiona, embora não vá além:

PROCESSUAL CIVIL E PROCESSUAL PENAL. CONFLITO DE COMPETÊNCIA POSITIVO. SUSCITAÇÃO PELA ADVOCACIA-GERAL DA UNIÃO. JUÍZOS SUSCITADOS. ÓRGÃOS FRACIONÁRIOS DO STJ. SOBREPOSIÇÃO DE COMPETÊNCIAS. AUSÊNCIA. NÃO CONHECIMENTO DO INCIDENTE. IDENTIFICAÇÃO DA CONTROVÉRSIA

1. Trata-se de Conflito de Competência (positivo) suscitado pela Advocacia-Geral da União, no qual se alega que a matéria versada no Mandado de Segurança 26.627/DF, impetrado por Luiz Inácio Lula da Silva na Primeira Seção do STJ, é estritamente penal e, por isso, deveria ser processada nas Turmas e Seção com competência criminal, designadamente a Quinta Turma e a Terceira Seção, onde está em curso o AgRg no REsp 1.765.139/PR.

2. No mencionado MS 26.627/DF objetiva-se a concessão da segurança "a fim de que se franqueie acesso à cópia integral de todos os eventuais registros relativos ao intercâmbio de informações, contatos, encontros, provas, procedimentos e investigações entre as autoridades locais e norte-americanas no âmbito da 'Operação Lava Jato', nos termos da Investigação Defensiva comunicada na origem por meio de correspondência encaminhada em 16.03.2020, ou, então, para que referido órgão esclareça e certifique que não participou dessa cooperação internacional com os Estados Unidos da América na condição de autoridade central na forma prevista no Decreto n. ${ }^{\circ} 3.810 / 2001 "$.

3. Foi deferida medida liminar para suspender a ordem emanada na liminar concedida no MS 26.627/DF (fls. 43-45) pelo eminente Ministro Sérgio Kukina. A liminar suspensa tem o seguinte teor: "defiro, apenas em parte, o pedido de medida liminar, determinando à autoridade coatora - Excelentíssimo Ministro de Estado da Justiça e Segurança - que informe ao impetrante, única e tão somente, sobre a existência, ou não, de pedidos de cooperação internacional formulados por autoridades Judiciárias brasileiras ou americanas (EUA), com base no acordo referido no Decreto 3.810/01, que tenham tramitado ou ainda tramitem perante a Autoridade Central brasileira (DRCI), tendo por foco as específicas 6 (seis) ações penais a que responde o impetrante no âmbito da Operação Lava Jato, todas identificadas e numeradas na nota de rodapé n. 12, da página 11 da petição inicial destes autos; em caso de inexistirem pedidos de cooperação internacional relacionados aos mencionados processos penais, deverá a autoridade impetrada, do mesmo modo, informar acerca dessa inexistência; fixo, outrossim, o prazo de 5 (cinco) dias úteis, a contar da publicação desta decisão, para o atendimento da presente medida, comunicando-se a este relator sobre o seu cumprimento".

ANÁLISE DO CONHECIMENTO DO CONFLITO

4. O writ impetrado por Luiz Inácio Lula da Silva visa ao acesso a documentos em posse de autoridade administrativa (Ministro de Estado da Justiça e Segurança Pública), o que demonstra competência da Primeira Seção, não importando se o conteúdo ou o destino posterior de sua utilização envolvam questão penal.

5. Estaria caracterizado o conflito positivo apenas se a Quinta Turma também tivesse declarado sua competência para apreciar o pedido de acesso administrativo, o que não se verifica.

6. Como informado pelo Ministro Felix Fischer, a petição incidental apresentada pelo ora interessado Luiz Inácio Lula da Silva, nos autos do REsp 1.765.139/PR, pleiteava acesso aos precitados Termos de Cooperação, que estariam tramitando sob sigilo perante a $13^{\mathrm{a}}$ Vara Federal de Curitiba/PR.

7. Não se pleiteou, no juízo suscitado penal, acesso aos documentos à autoridade administrativa impetrada no MS 26.627/DF, o que por si só resulta na conclusão de que não há conflito positivo entre os juízos suscitados. Não bastasse isso, a Quinta Turma do STJ, no AgRg no REsp 1.765.139/PR, decidiu não conhecer do pedido, por total impertinência temática com a questão de fundo tratada na Ação Penal. 


\section{ANÁLISE DE POSSÍVEL PERDA DE OBJETO \\ EM RAZÃO DO DECIDIDO PELO STF NA RCL 43.007}

8. Por provocação da Ministra Maria Thereza de Assis Moura, passa-se a analisar possível perda de objeto em virtude de recente decisão proferida pelo Ministro Ricardo Lewandowski na Reclamação 43.007 com o seguinte teor: "Diante de todo o exposto, julgo procedente o pedido para, confirmando a medida cautelar, determinar ao Juízo da $13^{\mathrm{a}}$ Vara Federal Criminal da Subseção Judiciária de Curitiba/PR que libere, incontinenti, o acesso da defesa aos elementos de prova e demais dados constantes do Acordo de Leniência 5020175-34.2017.4.04.7000 que façam referência ao reclamante ou que lhe digam respeito, notadamente: (i) ao seu conteúdo e respectivos anexos; (ii) à troca de correspondência entre a 'Força Tarefa da Lava Jato' e outros países que participaram, direta ou indiretamente, da avença, como, por exemplo, autoridades dos Estados Unidos da América e da Suíça; (iii) aos documentos e depoimentos relacionados aos sistemas da Odebrecht; (iv) às perícias da Odebrecht, da Polícia Federal, do MPF e realizadas por outros países que, de qualquer modo, participaram do ajuste; e (v) aos valores pagos pela Odebrecht em razão do acordo, bem assim à alocação destes pelo MPF e por outros países, como também por outros órgãos, entidades e pessoas que nele tomaram parte. $\mathrm{O}$ acesso a tais dados só poderá ser limitado - e desde que de forma motivada e pormenorizada - caso contemple informações tão somente referentes a terceiros ou que possam concretamente comprometer eventuais diligências em andamento. Reforço, ainda, que a presente decisão deve ser cumprida independentemente de prévia intimação ou manifestação do MPF, da Odebrecht ou de quem quer que tenha participado do referido Acordo de Leniência, sobretudo para impedir que venham a obstar ou dificultar o fornecimento dos elementos de prova cujo acesso o STF autorizou à defesa do reclamante. Por fim, após uma cognição exauriente dos autos, concluo que a determinação acima exarada deve estender-se a todos elementos probatórios e demais informações que se encontrem em expedientes conexos à Ação Penal e ao Acordo de Leniência acima referidos, digam eles respeito à Odebrecht ou a outras pessoas jurídicas de direito público ou privado, ainda que envolvam autoridades estrangeiras, desde que tais dados tenham sido ou possam ser empregados pela acusação contra o reclamante ou tenham a aptidão de contribuir para a comprovação de sua inocência. O prazo para as alegações finais nos autos da Ação Penal 5063130-17.2016.4.04.7000 somente deverá ter início após o cabal cumprimento desta decisão, ficando prejudicado, consequentemente, o pedido de declaração de nulidade dos atos praticados a partir do despacho judicial impugnado nesta reclamação. Publique-se. Brasília, 16 de novembro de 2020".

9. Ressalta-se que a decisão acima é exauriente e confirma decisão cautelar proferida em 2.9.2020 com o mesmo teor, mas o Conflito de Competência ora em análise foi ajuizado pela União em 9.9.2020.

10. Não há perda de objeto do presente Conflito de Competência por o ex-Presidente da República ter supostamente conseguido acesso aos documentos controvertidos, pois tal questão diz respeito ao mérito das ações que dão origem ao presente Conflito, sendo nelas o juízo próprio para declaração de perda de objeto pelo acesso aos documentos.

11. Ocorreria a perda de objeto do presente Conflito de Competência se em uma das ações originárias houvesse declaração de carência de interesse processual da parte que persegue a resposta jurisdicional.

CONCLUSÃO

12. Sendo o presente Conflito incognoscível, a medida liminar deferida é revogada, e a análise da tutela provisória pleiteada por Luiz Inácio Lula da Silva nas fls. 80-90 fica prejudicada.

13. Conflito de Competência não conhecido.

(CC 174.706/DF, Rel. Ministro HERMAN BENJAMIN, CORTE ESPECIAL, julgado em 18/11/2020, DJe 18/12/2020. Grifou-se). 
No Supremo Tribunal Federal, a pesquisa nada encontrou de relevante. O próprio acórdão referido pelo STJ na decisão acima — o da Reclamação 43.007 — não discorre sobre a investigação defensiva:

RECLAMAÇÃO CONSTITUCIONAL. DESCUMPRIMENTO, POR PARTE DO JUÍZO DE PISO, DE DECISÕES PROFERIDAS POR ESTA SUPREMA CORTE. ACESSO A ELEMENTOS DE PROVA JÁ COLIGIDOS DENEGADO AO RECLAMANTE. INOBSERVÂNCIA, ADEMAIS, DA SÚMULA VINCULANTE 14. "PEDIDO DE RECONSIDERAÇÃO". INSTRUMENTO QUE NÃO SE PRESTA A IMPUGNAR DECISÕES JUDICIAIS À FALTA DE PREVISÃO LEGAL. PETIÇÃO APRESENTADA POR PROCURADORES DA REPÚBLICA, PLEITEANDO, EM NOME PRÓPRIO E DE TERCEIROS INOMINADOS COM O OBJETIVO DE IMPEDIR QUE O RECLAMANTE OBTENHA DADOS PERTINENTES À SUA DEFESA. ATUAÇÃO INSTITUCIONAL DO PARQUET PERANTE O STF. ATRIBUIÇÃO EXCLUSIVA DA PROCURADORIA-GERAL DA REPÚBLICA. CONVERSAS PRIVADAS E INTERESSES DE TERCEIROS PROTEGIDOS POR RIGOROSO SIGILO JÁ DECRETADO. VALIDADE DAS PROVAS OBTIDAS. MATÉRIA QUE REFOGE AO ÂMBITO DA PRESENTE RECLAMAÇÃO. PETIÇÃO DA QUAL NÃO SE CONHECE.

I - Os pedidos de reconsideração, tal como o presente, carecem de qualquer respaldo no regramento processual vigente. Não constituem recursos, em sentido estrito, e nem mesmo meios de impugnação atípicos. Por isso, não suspendem prazos e tampouco impedem a preclusão. Inexiste fundamento normativo que autorize entendimento em sentido contrário, sobretudo à luz do que dispõem os artigos 223, 278 e 507 do Código de Processo Civil de 2015.

II - Nos autos desta reclamação o Parquet atua com fundamento no art. 46 da Lei Complementar 75/1993 (Lei Orgânica do Ministério Público), que atribui competência exclusiva à Procuradoria-Geral da República para oficiar nos processos em curso perante STF.

III - Ao exercer suas atribuições como dominus litis, o Ministério Público não formula pleitos em nome próprio, mas em caráter institucional, afigurando-se, portanto, manifesta a ausência de legitimidade postulatória dos peticionantes, de maneira a impedir que integrantes do MPF, de primeiro grau, totalmente alheios à lide, intervenham nos autos para impugnar decisões tomadas por esta Suprema Corte, a pretexto de defender direitos próprios e de terceiros.

IV - Trata-se de pleito claramente inadmissível, pois, mesmo que, com ele, se busque resguardar interesses institucionais, como seria o caso da pretendida declaração de nulidade de elementos probatórios a serem juntados em ações penais movidas contra o reclamante - matéria, aliás, totalmente alheia à presente reclamação - tal via de impugnação somente poderia ser manejada, no âmbito da Suprema Corte, pelo Procurador-Geral da República, na qualidade de titular da ação penal, jamais por um litisconsórcio de Procuradores a ele funcionalmente subordinados, agindo em nome próprio e assistidos por advogado particular.

V - O Código de Processo Civil é expresso ao consignar, em seu art. 18, que a ninguém é dado pleitear direito alheio em nome próprio, salvo quando autorizado pelo ordenamento jurídico, o que não é o caso. Na espécie, não há qualquer direito transindividual a justificar a atuação do órgão ministerial de piso em legitimação extraordinária, na qualidade de substituto processual.

VI - Ainda que se admita, apenas para argumentar, que o ingresso dos peticionantes nos autos teria o escopo de, supostamente, defender terceiras pessoas, de resto inominadas, em todas as decisões anteriores constantes destes autos, autorizando o acesso do reclamante ao material apreendido na Operação Spoofing, ficou ressalvado, de forma expressa, que os conteúdos que digam respeito exclusivamente a terceiros, isto é, aqueles que não tenham qualquer relação com o reclamante, devem ser mantidos sob rigoroso sigilo.

VII - Diante disso, fica afastada qualquer legitimidade recursal dos peticionantes seja para a defesa de interesses institucionais, seja deles próprios, seja ainda de terceiros, estes, registre-se, não demonstrados. 


\begin{abstract}
VIII - Na presente reclamação, os personagens processuais dotados de legitimidade recursal são apenas o PGR, enquanto chefe do Parquet Federal, e o próprio reclamante, como lídimo interessado, por figurar como réu na supra referida ação penal.

IX - Tais atores são únicos polos legitimados para pedir e contestar as providências que são objeto da presente ação, inclusive mediante agravo interno ou embargos de declaração, sempre, porém, na forma e nos prazos previstos na legislação pertinente. $X$ - Petição da qual não se conhece em face da manifesta ilegitimidade recursal dos peticionantes.

(Rcl 43007 AgR, Relator(a): RICARDO LEWANDOWSKI, Segunda Turma, julgado em 09/02/2021, PROCESSO ELETRÔNICO DJe-071 DIVULG 14-04-2021 PUBLIC 15-04-2021).
\end{abstract}

Apesar de o substancioso voto do relator tangenciar o tema objeto deste trabalho, em verdade não o enfrenta, até porque a questão, no caso concreto, morreu em face de razões processuais e os aspectos mais propriamente tocantes à investigação defensiva não pareciam estar no cerne da discussão da medida judicial utilizada.

Sendo essa a situação, continua a investigação defensiva sem uma definição jurisprudencial sobre sua constitucionalidade, sobre seus contornos, sobre seus limites, de forma que permanece como um instituto ainda não definitivamente estabilizado no Direito nacional.

\title{
7 Novos rumos da investigação defensiva
}

Em que pese a delonga na tramitação da necessária reforma do Decreto-Lei n ${ }^{\circ} 3.689$, de 3 de outubro de 1941 - Código de Processo Penal —, verificaram-se avanços quanto ao direito ao contraditório do investigado, ao menos lhe assegurando o direito de ser ouvido antes de encerrada a investigação criminal. Esse é o entendimento que se extrai do art. 14, caput e parágrafo único, do texto original do anteprojeto de reforma do Código de Processo Penal Projeto de Lei do Senado no 156/2009:

\footnotetext{
Art. 14. É facultado ao investigado, por meio de seu advogado ou de outros mandatários com poderes expressos, tomar a iniciativa de identificar fontes de prova em favor de sua defesa, podendo inclusive entrevistar pessoas.

Parágrafo único. As entrevistas realizadas na forma do caput deste artigo deverão ser precedidas de esclarecimentos sobre seus objetivos e do consentimento das pessoas ouvidas. $^{3}$
}

Como destaca Talon (2020, p. 65), o mencionado dispositivo facultava à defesa do investigado a tomada da iniciativa de identificar fontes de prova em favor de sua defesa, inclusive entrevistando pessoas. Esclarece o autor, ainda, que as entrevistas deveriam ser

\footnotetext{
${ }^{3}$ Anteprojeto de reforma do Código de Processo Penal - Projeto de Lei do Senado n. 156/2009.
} 
precedidas de esclarecimentos sobre seus objetivos e da obtenção do consentimento dessas pessoas quanto a serem ouvidas pela defesa.

Outrossim, após a aprovação em plenário, o Projeto de Lei foi remetido à Câmara dos Deputados, passando a tramitar como Projeto de Lei $n^{\circ}$ 8.045/2010. No texto, verifica-se, em continuidade, evidente aprofundamento dos contornos e limites das entrevistas a serem promovidas pela defesa do investigado. Isso porque houve ajuste no texto original e o acréscimo de cinco parágrafos, conforme é possível verificar adiante:

\footnotetext{
Art. 13. É facultado ao investigado, por meio de seu advogado, de defensor público ou de outros mandatários com poderes expressos, tomar a iniciativa de identificar fontes de prova em favor de sua defesa, podendo inclusive entrevistar pessoas. $\S 1^{\circ}$ As entrevistas realizadas na forma do caput deste artigo deverão ser precedidas de esclarecimentos sobre seus objetivos e do consentimento formal das pessoas ouvidas.

$\S 2^{\circ} \mathrm{A}$ vítima não poderá ser interpelada para os fins de investigação defensiva, salvo se houver autorização do juiz das garantias, sempre resguardando o seu consentimento.

$\S 3^{\circ} \mathrm{Na}$ hipótese do $\S 2^{\circ}$ deste artigo, o juiz das garantias poderá, se for o caso, fixar condições para a realização da entrevista.

$\S 4^{\circ}$ Os pedidos de entrevista deverão ser feitos com discrição e reserva necessárias, em dias úteis e com observância do horário comercial.

$\S 5^{\circ} \mathrm{O}$ material produzido mencionado poderá ser juntado aos autos do inquérito, a critério da autoridade policial.

$\S 6^{\circ}$ As pessoas mencionadas no caput deste artigo responderão civil, criminal e disciplinarmente pelos excessos cometidos. ${ }^{4}$
}

Pode-se constatar que, mesmo não tendo sido ainda aprovada a reforma do Código de Processo Penal, tais mecanismos existentes nos Projetos de Lei provavelmente contribuíram para a elaboração e regulamentação das diretrizes da investigação defensiva consubstanciada no Provimento $n^{\circ}$ 188/2018 do Conselho Federal da Ordem dos Advogados do Brasil.

Assim, lembra Araújo (2017, p. 234) que, não obstante as redações dos Projetos de Lei se apresentando de forma mais singela do que as diretrizes delineadas pelo Provimento $\mathrm{n}^{\circ}$ 188/2018, a inclusão da matéria trouxe maior atenção da doutrina para a questão.

Para Augusto Eduardo de Souza Rossini e Spencer Toth Sydow:

Em síntese, a Investigação Defensiva - que está dando os seus primeiros passos em nosso sistema jurídico - apresenta-se como verdadeira e eficaz ferramenta na busca da verdade e fundamentalmente na efetivação da paridade de armas entre o estado forte - com todo o seu arsenal institucional e orçamentário, e o advogado e seu constituído. (ROSSINI; SYDOW, 2020).

Portanto, verifica-se que a investigação defensiva continua evoluindo, inclusive quanto aos instrumentos normativos que tratam do assunto, ou ao menos de parcela dele, como se vê

\footnotetext{
${ }^{4}$ Projeto de Lei no 8.045/2010. Código de Processo Penal. Projeto de Lei no 8.045/2010. Código de Processo Penal.
} 
pelo Projeto de Lei nº 8.045/2010, que assegurará por lei a realização, no caso, de pelo menos uma das atividades da investigação defensiva, que são as entrevistas por parte de defensor do investigado.

\section{Considerações finais}

Em razão dos argumentos e análises acima expostos, foi possível constatar que a investigação defensiva continua sendo pouco difundida no Direito pátrio, especialmente por conta da falta de norma legislativa específica quanto ao tema, que estabeleça suas condições, meios e limites, hábil a dissipar de vez as discussões acerca de sua viabilidade, legalidade e constitucionalidade, apesar da existência do Provimento nº 188/2018 do Conselho Federal da Ordem dos Advogados do Brasil, que muito bem materializou as atividades de investigação defensiva, assim como o campo de sua utilização, que, em tese, não precisa se restringir à fase preliminar, mas pode alcançar toda a instrução processual em juízo, na fase recursal em qualquer grau, inclusive durante a execução da pena.

Também foi possível constatar a preocupação e diferentes posicionamentos doutrinários quanto a observância ou não do contraditório na fase preliminar da persecução penal.

Após a análise e confrontação de ângulos variados de abordagem do tema, foi possível constatar que a matéria vem sendo tratada por operadores do Direito há muitos anos, tendo, contudo, ganhado maior atenção da doutrina após sua inclusão no anteprojeto de reforma do Código de Processo Penal, Projeto de Lei do Senado no 156/2009, que, após aprovado em plenário pelo Senado Federal, foi remetido à Câmara dos Deputados, sendo rotulado como Projeto de Lei $n^{\circ} 8.045 / 2010$, que prevê a possibilidade de o investigado, na pessoa de seu defensor, tomar a iniciativa de identificar fontes de provas em favor de sua defesa, podendo inclusive entrevistar pessoas, a fim de colher subsídios para defendê-lo.

É notável a divisão no mundo jurídico em relação à constitucionalidade da investigação defensiva e seus reais contornos e limites, faltando uma decisão do STF — preferencialmente de caráter vinculante - capaz de pôr um ponto final no debate.

Parece induvidoso que o instrumento da investigação defensiva se conforma à paridade de armas no processo penal e, nessa toada, acha guarida nos princípios da igualdade (art. $5^{\circ}$, caput, da Constituição), do devido processo legal (seu art. $5^{\circ}$, LIV), bem assim do contraditório e da ampla defesa (idem, art. $5^{\circ}$, LV) e até mesmo no art. 144 ainda da Carta Política, uma vez que a segurança pública, a par de constituir dever do Estado, é ali consagrada não apenas como direito, mas também como responsabilidade de todos. Isso daria respaldo ao multicitado 
Provimento $\mathrm{n}^{\mathrm{o}}$ 188/2018 do CFOAB, mas os argumentos em contrário, relatados neste artigo, não são desprezíveis e o STF ainda não se pronunciou sobre o assunto.

Apesar disso, conclui-se que a pesquisa logrou êxito em responder aos questionamentos iniciais, notadamente a conceituação da investigação defensiva, a evolução do tema durante os anos, a discussão sobre sua constitucionalidade e viabilidade, e ainda os caminhos já trilhados, junto com os desafios que ainda tem de enfrentar, para melhor reconhecimento e aplicabilidade das atividades investigativas por parte do investigado.

\section{Referências}

ARAÚJO, Marcelo Azambuja. Considerações sobre o tratamento da investigação criminal defensiva no PLS n. 156/09. Revista Justiça e Sistema Criminal, v. 9, n. 16, p. 233-246, jan./jun. 2017. Disponível em:

https://revistajusticaesistemacriminal.fae.edu/direito/article/view/104. Acesso em: 22 jun. 2021.

BALDAN, Édson Luís. Investigação defensiva: o direito de defender-se provando. Revista Brasileira de Ciências Criminais, São Paulo, n. 64, v. 15, p. 253-273, jan./fev. 2007.

BRASIL. Anteprojeto de reforma do Código de Processo Penal - Projeto de Lei do Senado no 156/2009. Congresso Nacional. Disponível em: https://legis.senado.leg.br/sdleggetter/documento?dm=2966191\&ts=1594032503458\&disposition=inline. Acesso em: 19 jun. 2021.

BRASIL. Constituição da República Federativa do Brasil de 1988. Brasília, DF: Presidência da República, [2020]. Disponível em: http://www.planalto.gov.br/ccivil_03/constituicao/constituicao.htm. Acesso em: 27 jun. 2021.

BRASIL. Decreto-Lei no 3.689 de 03 de outubro de 1941. Código de Processo Penal. Diário Oficial da União, Brasília, 13.10.1941 e retificado em 24.10.1941. Disponível em:

http://www.planalto.gov.br/ccivil_03/decreto-lei/del3689compilado.htm. Acesso em: 20 jun. 2021.

BRASIL. Lei $\mathbf{n}^{\circ}$ 8.906, de 4 de julho de 1994. Dispõe sobre o Estatuto da Advocacia e a Ordem dos Advogados do Brasil (OAB). Diário Oficial da União, Brasília, DF, 5 jul. 1994. Disponível em: http://www.planalto.gov.br/ccivil_03/leis/L8906.htm. Acesso em: 20 jun. 2021.

BRASIL. Lei $\mathbf{n}^{\mathbf{0}}$ 12.830, de 20 de junho de 2013. Dispõe sobre a investigação criminal conduzida pelo delegado de polícia. Diário Oficial da União, Brasília, DF, 20 jun. 2013. Disponível em: http://www.planalto.gov.br/ccivil_03/_ato2011-2014/2013/lei/112830.htm. Acesso em: 28 jun. 2021.

BRASIL. Ordem dos Advogados do Brasil. Provimento n. 188/2018. Diário Eletrônico da Ordem dos Advogados do Brasil. Disponível em: https://deoab.oab.org.br/pages/materia/19. Acesso em: 19 jun. 2021. 
BRASIL. Projeto de Lei $\mathbf{n}^{\mathbf{0}}$ 8045/2010. Código de Processo Penal. Congresso Nacional. Disponível em:

https://www.camara.leg.br/proposicoesWeb/prop_mostrarintegra?codteor=1638152\&filenam $\mathrm{e}=\mathrm{PL}+8045 / 2010$. Acesso em: 19 jun. 2021.

BRASIL. Resolução 181/2017. Conselho Nacional do Ministério Público. Disponível em: https://www.cnmp.mp.br/portal/images/Resolucoes/Resoluo-181-1.pdf. Acesso em: 28 jun. 2021.

BRASIL. Supremo Tribunal Federal. Recurso Extraordinário 593.727 - Minas Gerais. Supremo Tribunal Federal. Ano 2015. Disponível em:

https://redir.stf.jus.br/paginadorpub/paginador.jsp?docTP=TP\&docID=9336233. Acesso em: 28 jun.2021.

BRASIL. Supremo Tribunal Federal. Súmula Vinculante 14. 2009. Disponível em: http://www.stf.jus.br/portal/jurisprudencia/menuSumario.asp?sumula=1230. Acesso em: 20 jun. 2021.

HOFFMANN, Henrique; FONTES, Eduardo. Advogado não pode fazer investigação criminal defensiva. Conjur: Consultor Jurídico, 29 jan. 2019. Disponível em:

https://www.conjur.com.br/2019-jan-29/academia-policia-advogado-nao-realizarinvestigacao-criminal. Acesso em: 28 jun. 2021.

LOPEZ JÚNIOR, Aury. Sistemas de investigação preliminar no processo penal. 3. ed. Rio de Janeiro: Lumen Juris, 2005.

MACHADO, André Augusto Mendes. A investigação criminal defensiva. Dissertação (Mestrado em Direito) - Faculdade de Direito, Universidade de São Paulo, 2009. Disponível em: https://www.teses.usp.br/teses/disponiveis/2/2137/tde-27082009-

114835/publico/Andre_Augusto_Mendes_Machado_Dissertacao.pdf. Acesso em: 20 jun. 2021.

MELO, Valber; FARIA, Fernando; BROETO, Filipe Maia. Procedimento de investigação defensiva - 'PID': um debate necessário. Olhar Jurídico. 19 jun. 2020. Disponível em: https://www.olharjuridico.com.br/artigos/exibir.asp?id=924\&artigo=procedimento-deinvestigacao-defensiva-pid-um-debate-necessario. Acesso em: 27 jun. 2021.

MILANEZI, Raissa de Cavassin. Investigação Criminal Defensiva. Empório do Direito. 20 nov. 2020. Disponível em: https://emporiododireito.com.br/leitura/investigacao-criminaldefensiva. Acesso em: 28 jun. 2021.

ORDEM DOS ADVOGADOS DO BRASIL. Provimento n. 188/2018. Diário Eletrônico da Ordem dos Advogados do Brasil. https://deoab.oab.org.br/pages/materia/19. Acesso em 19 jun. 2021

PEDROSA, Simon Francisco. Investigação defensiva. Revista do CAAP, v. 24, n. 2, p. 47 72, 2019. Disponível em:

https://revistadocaap.direito.ufmg.br/index.php/revista/article/view/489. Acesso em: 28 jun. 2021. 
PRADO, Geraldo. O estatuto jurídico da acusação e o Projeto de Lei Anastasia-Streck - parte I. Consultor Jurídico. 3 mar. 2020. Disponível em: https://www.conjur.com.br/2020-mar03/geraldo-prado-estatuto-acusacao-pl-anastasia-streck. Acesso em: 27 jun. 2021.

ROSSINI, Augusto Eduardo de Souza; SYDOW, Spencer Toth. O Provimento n. 188/2018 e a Investigação Defensiva: uma nova frente de atuação da advocacia no Direito Penal Informático. Meu Site Jurídico. 20 jul. 2020. Disponível em: https://meusitejuridico.editorajuspodivm.com.br/2020/07/20/o-provimento-n-1882018-einvestigacao-defensiva-uma-nova-frente-de-atuacao-da-advocacia-no-direito-penalinformatico/. Acesso em: 27 jun. 2021.

SILVA, César Dario Mariano. A inconstitucionalidade da investigação defensiva instituída pela OAB. Conjur: Consultor Jurídico, 28 maio 2019. Disponível em:

https://www.conjur.com.br/2019-mai-28/cesar-dario-inconstitucionalidade-investigacaodefensiva?imprimir=1. Acesso em: 27 jun. 2021.

TALON, Evinis. Investigação criminal defensiva. Gramado/RS: ICCS - Internacional Center for Criminal Studies, 2020.

ZANARDI, Tatiane Imai. Investigação Criminal Defensiva: uma prática a ser difundida. Revista Justiça e Sistema Criminal, v. 8, n. 14, p. 191-216, jan./jun. 2016. Disponível em: https://revistajusticaesistemacriminal.fae.edu/direito/article/view/71. Acesso em: 20 jun. 2021. 